\title{
Experimental Organism Benign Seminoma
}

National Cancer Institute

\section{Source}

National Cancer Institute. Experimental Organism Benign Seminoma. NCI Thesaurus.

Code C112276.

A benign germ cell neoplasm of the testis. (CDISC) 